convinced him, though he had not seen these finds in situ, that he was dealing with diluvial man, the heterogeneous character of the finds, which included Venetian glass, as well as knives and axes of stone which would now be termed neolithic, only provoked ridicule when submitted to expert examination. Boucher de Perthes then reverted to the idea that they belonged to a 'Celtic' civilization, though still maintaining their association with an extinct fauna. It was not until 1843 or 1844 that he saw, in situ, the first of the axes, now to be regarded as Lower Palæolithic, which confirmed his contention of the existence of diluvial man. This find from the H.opital site heralded the evidence which, notwithstanding such vagaries as a large proportion of fractured flints of non-human origin, and a collection of so-called representations of animal forms, was to win a verdict in his favour from the British commission of inquiry of 1859 .

So far as the foundation of prehistory was the outcome of anything like a scientific conception of the aims and methods of archæology, the credit belongs to Picard rather than to Boucher de Perthes ; but to the latter must be conceded a tenacity of purpose which carried through the actual investigation and won recognition in the end.

\title{
The Proposed Everglades National Park, U.S.A.
}

\section{By Dr. John Kunkel Small, New York Botanical Garden}

THE proposed Everglades National Park, recently authorized by the Congress of the United States, after thirty years agitation, is of importance to all who are interested in outdoor life. Its area (capable of enlargement) of two thousand square miles is less than that of several national parks in the United States and elsewhere ; but it surpasses in the abundance, variety, and activity of plant and animal life. In most large parks life is in a decline. Variety is giving way to uniformity. Erosion is tearing down mountains ; species are disappearing; plant and animal life is maintained with difficulty in increasingly artificia] conditions. Such is not the case in the Everglades. Both at the outer fringes of mangroves and far within, land is naturally and continually increasing. Life in the warm humid climate is luxuriant, active-primeval, as if species were making. Plants and animals live as they have for ages, and as they may continue to live for years to come.

The area (Fig. 1) is not technically within the tropies, but the Tropic of Cancer lies only seventyfive miles distant, and ocean currents, prevailing winds, and migratory birds have found a strictly tropical rendezvous scarcely surpassed anywhere in congenial conditions and lack of disadvantages. The area is about equally divided between land and water. The highest points of land are scarcely ten feet above tide, and the water has an average depth of but a fathom or so. Most of the area is accessible by boat in protected waters, a mode of transportation least disturbing to wild life. However, when roads and trails are desirable they can be built at little expense.

\section{Animal Life}

There are few places where marine life is so abundant and active; the greater part of it is in continuous motion and change, either anchored or free swimming. On one hand, this fact can be observed and studied in the shallow crystal-clear waters of the vast continental shelf on which the Florida Keys now stand and which fringe the mainland. These waters are teeming with life, in almost innumerable quantities and variety. A handful of mud from a bleak and lofty area like the United States Great Smoky Mountain Park will remain motionless; a handful from the Bay of Florida will be in continuous motion as a result of the included active marine life. The kinds of lowest animals-sponges, jellyfish, corals, seaanemones, moss-animals, molluscs, sea-urchins, seacucumbers, starfish and stone lilies-are legion.

Associated with these, fish of almost innumerable kinds, forms, and colours, and great range in size, abound in the waters, fresh and salt. The vast numbers of fish may be realized by the fact that the schools are often so large that they fill bays and sounds to the exclusion of a great part of the water.

Ascending in the life-scale, we find amphibians and reptiles. Frogs abound. Several kinds of large turtles are found, and the alligator and the crocodile are outstanding. Among serpents is the dangerous cotton-mouth moccasin and thelargestand mostdan. gerous American reptile, the diamond-back rattlesnake, which sometimes attains a length of nine feet. Lizards are numerous, but most of them are small.

More evident than the amphibians and reptiles are the birds. The bird life of this region is prodigious, ranging from the minute humming-bird to 
the wood ibis and the golden eagle. Naturally, from the make-up of the country, both land and water birds abound. The latter are often seen in greater abundance. As a result of their feeding habits-diurnal and nocturnal-flocks of innumerable birds, like flakes of snow in a storm, may be seen in flight both day and night. The sight of their going and coming between the feedinggrounds on a bright moonlight night, not to mention the uncanny noises of their cries and the swish of wings, is something never to be forgotten. Black and various colours of plumage are continually seen. Very conspicuous are the white and pink ibis and the rare roseate spoonbill, of which thousands, even hundreds of thousands, were

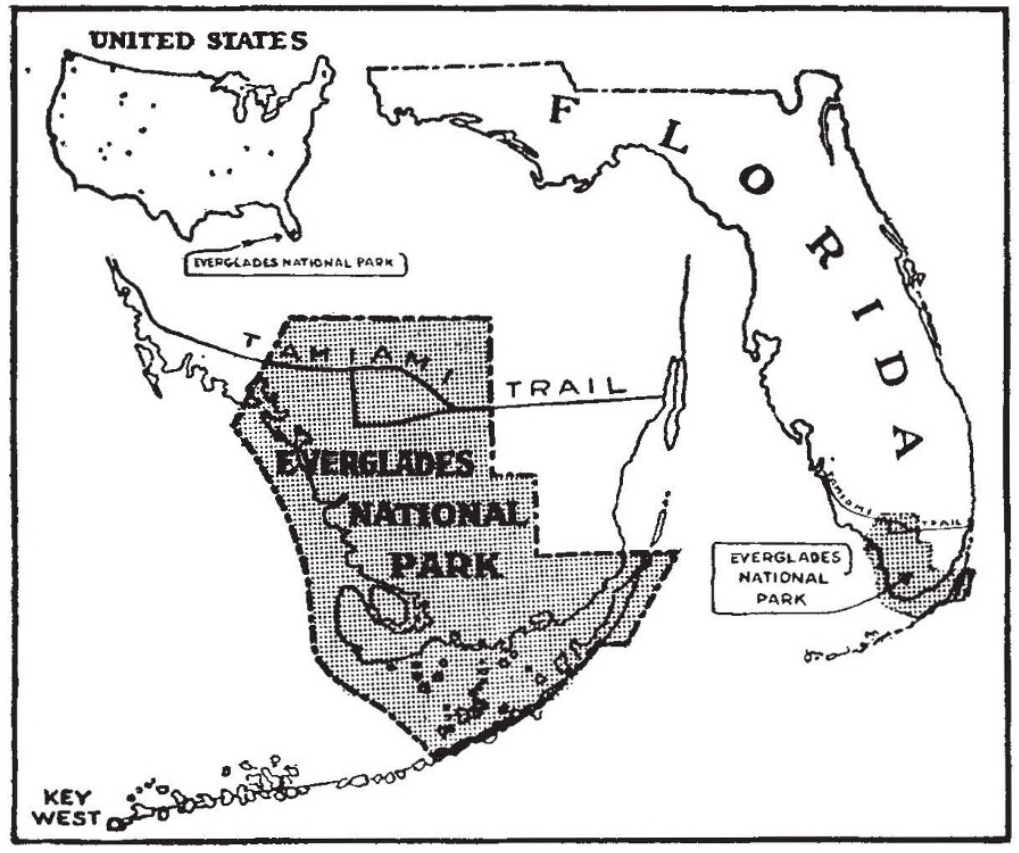

Fig 1.

The Proposed Everglades National Park. of eastern North America roam through the wilderness. Prominent among these are the panther, lynx, bear, deer. Curiously enough, the otter lives here just as it does in the Hudson Bay region. The larger aquatic mammals are the massive sea-cow and the whale.

\section{Plant Life}

Broad-leaved vegetation is the most evident form of plant life to the casual observer, whether it be in swamp, prairie, or hammock ; but underneath it grow ferns and flowering plants bewildering in attractiveness and variety. In this tropical wilderness, vegetation grows to its full stature and natural age without interference from man. It is true the destructiveness of Nature is rampant; but it is normal and in its way orderly. Plants and animals grow rapidly and soon return to dust, a process hastened here by a moist warm climate and the presence of a host of fungi and bacteria ever ready to do their work. In spite of the natural inroads, as the source of supply is inexhaustible, the flora is maintained while the land gradually rises higher and higher above the tides.

In the Everglades, tropical vegetation dominates; but the ranges of north temperate trees dovetail with those of the West Indian tropics. The north temperate elements have extended southward through the hammocks and along the cool waters of the prairies. The tropical ones have been brought beyond the tropics by the warm ocean currents, the winds, and the birds; and formerly seen at a time. The well-known egret is a decorative associate. The smaller highly coloured migratory birds pass this way, and are evident in season at this midway station.

On the land, one finds the insects universal as well as yet innumerable. The numbers of kinds can be only roughly estimated. Fascinating and grotesque forms may be seen everywhere. A short description of them would fill volumes. Many of the kinds are almost or quite microscopic ; but large and ornate butterflies and moths abound. Less graceful but fascinating are the devilshorses, a showy grasshopper commonly six inches long which travels over the land by the million devouring vegetation as it goes.

Mammals are present on the land and also in the water. Several species of the large quadrupeds thus plants of opposite temperature requirements mingle, and there is a unique balance in life-forms.

Withal it is a strange country, a land of anomalies and the grotesque. Here fish sing*; snakes often live in trees; epiphytes grow as terrestrials; terrestrials grow as epiphytes ; giant oak trees are arbours for aerial plants and ferns ; cacti grow in water; oysters grow on trees that dip into the creeks; large pine trees and broad-leaved trees grow on rocks lacking soil; fig-trees grow as petriphytes trying to strangle the rocks; giant palms more than a hundred feet tall and cactus trees thirty feet tall grow as humus-plants; strangler figs kill other trees, and often turn upon themselves and commit suicide.

* On the reef smail fish attach themselves to the hull of a boat after dark and give off their plaintive notes all night long. 